\title{
A Mathematics Education Research Agenda in Latin America Motivated by Coronavirus Pandemic
}

\author{
Walter F. Castro ${ }^{1 *}$, Luis R. Pino-Fan ${ }^{2}$, Jesus G. Lugo-Armenta ${ }^{2}$, Jorge A. Toro ${ }^{1 *}$, Silvia Retamal ${ }^{2}$ \\ 1 Universidad de Antioquia, COLOMBIA \\ 2 Universidad de Los Lagos, CHILE
}

Received 20 September 2020 - Accepted 12 November 2020

\begin{abstract}
The pandemic and its disruption of social dynamics, including school dynamics, necessitates a review of both the proposals for education in situations of confinement and the research that must be carried out to account for exceptional educational situations. It is likely that this pandemic is only the first circumstance that has highlighted the need to investigate more decisively areas that have not been previously considered or have been put aside. This document presents the case of three Latin American countries, Mexico, Colombia, and Chile, in relation to educational difficulties generated by the pandemic, with respect to regional actions on the educational problems that have been revealed, and proposes regional research agendas for the Mathematics Education research community.
\end{abstract}

Keywords: COVID-19, mathematics education, education agenda, teacher's strategies

\section{INTRODUCTION}

Mathematics Education has oriented its efforts, mainly, to the study of factors affecting mathematics teaching and learning processes, attending to the plurality of contexts, demands, and social needs, as well as scientific progress. Thus, both the problems and research agendas (Behr et al., 1984; Howson, 1988; Long, Meltzer, \& Hilton, 1970; Skovsmose, 2012; Wheeler et al., 1984; Wilson, 2020) that have been identified and addressed in the research in Mathematical Education have evolved depending on the educational reforms and changes in educational paradigms generated by such needs (Artigue, 1998; Inglis \& Foster, 2018; NCTM Research Committee, 2015).

Inglish and Foster (2018) identified 'turns of interest' in the recent history of Mathematics Education, in topics such as geometry, calculators, programming, computers, and others. More recently, 'turns' are recognized regarding the use of learning platforms (Henry, 2018; Johnson, Hornik, \& Salas, 2008), gamification (Cunha, Barraqui, \& de Freitas, 2018; Hamari, Koivisto, \& Sarsa, 2014), and mathematics learning outside of school through non-traditional methods such as gatherings, workshops, and mathematical circles (Kennedy \&
Smolinsky, 2016), all to improve mathematics learning processes with an impact on student motivation. These proposals have not been given much relevance, until now. Schoenfeld (2016) affirms, "What takes place in schools and classrooms is intimately connected to what happens in society at large" (p. 497). Lerhman (2000), recognizes the 'social turn' in Mathematics Education. Currently, a 'new social turn' is taking place in the world, induced by the Coronavirus 2019 pandemic (COVID-19), which will undoubtedly influence not only classrooms, schools, and universities, but also the world economy, among other aspects. Indeed, COVID-19 is causing a pandemic unheard of for the generations that inhabit the planet. As it is known, COVID-19 is a virus that originated in the Chinese city of Wuhan and so far has infected more than a thirty-six million people and has caused the death of approximately 1,057,996 around the world, mainly affecting Italy, Spain, the United States, Brazil, India, Mexico, the United Kingdom, France, and the list goes on.

In Latin America the first reported corona virus infected patients were those who had travelled to Europe and Asia, and the reported cases of viruspositive patients soon began to increase, adding $9,840,803$ confirmed cases as of October 07,2020 , and 


\section{Contribution to the literature}

- This paper aims at exploring COVID-19 pandemic effects in the education system of three LatinAmerican countries and at proposing a research agenda for the region's education community.

- The paper revisits problems and proposals in the literature of mathematics education, organizes, and links them to mathematics education problems unveiled by the pandemic.

- The paper identifies and groups the problems of mathematics education in the region that need both research and action to improve Latin-America mathematics education.

\section{Coronavirus cases in Latin America}

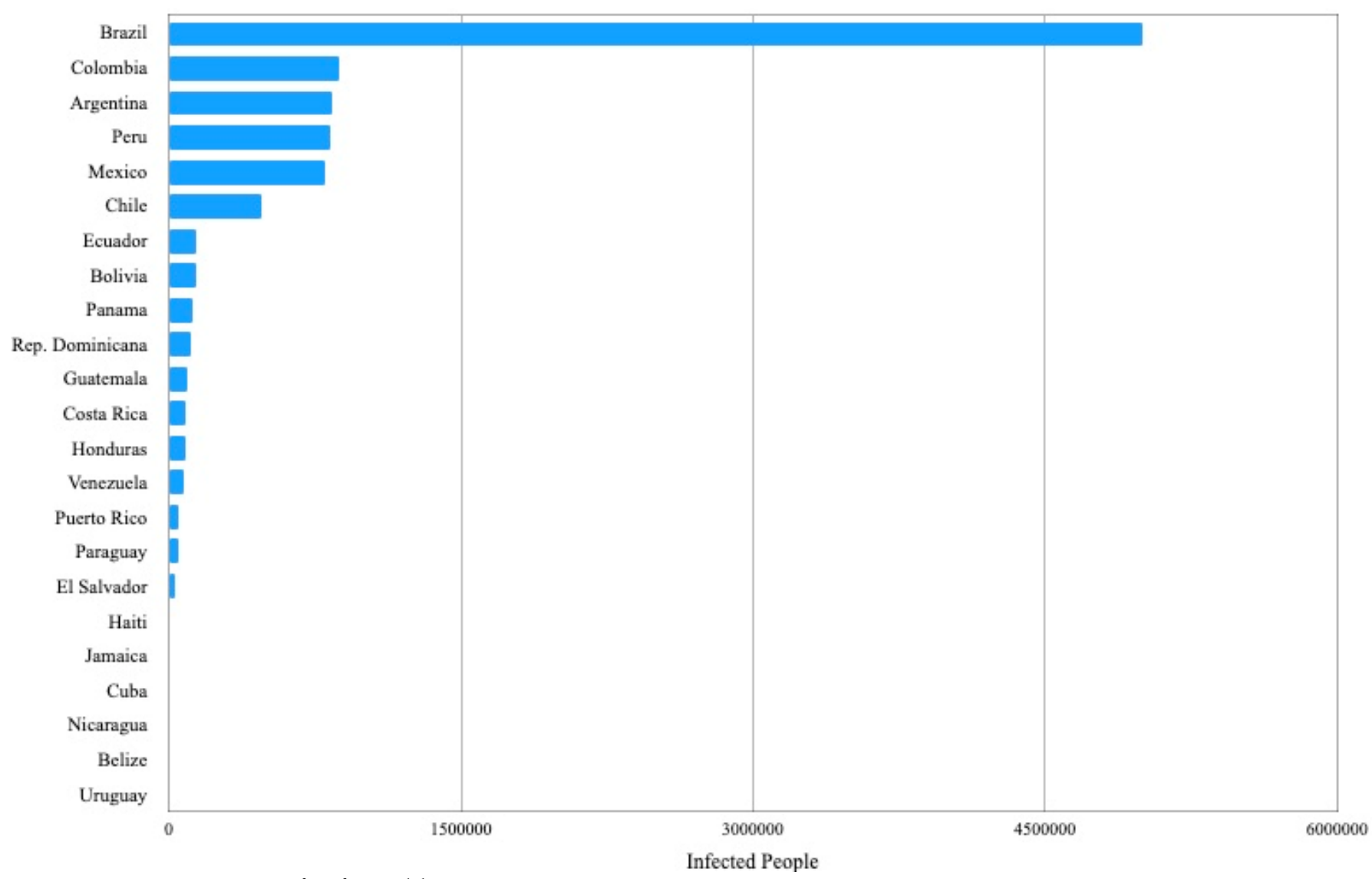

Figure 1. Frequencies of infected by COVID-19 in Latin America (Source: own elaboration based on John Hopkins University data)

above according to available data from John Hopkins University. In Figure 1, it can be seen that the Latin American countries with the highest number of cases are Brazil, Colombia and Argentina.

Figure 2 shows the evolution of the number of confirmed virus-infected citizens in Chile, Mexico, and Colombia, with Colombia being the country with the steepest slope, which is indicative of a substantial increase in virus infections.

Regarding forecasts of economic impact that this pandemic will have on Latin American countries, concerned as they are both with health contingencies caused by the pandemic and with the negative economic impact on their economies, the following containment measures have been implemented: a) establish periods of quarantine, voluntary or mandatory, to avoid the accelerated spread of the virus and to not saturate hospitals; b) total or partial border closure; c) school closure at all educational levels; d) measures to support the health sector such as buying medical equipment, increasing capacity to carry out tests to detect COVID-19 cases; e) fiscal support measures, both for companies and for citizens; f) cancellation of massive events and closure of public spaces.

Regarding item c), in most Latin American countries schools have been closed, as is the case in Mexico, Chile, and Colombia, therefore, teachers have to use technologies to continue their teaching, following a similar path to that followed by teachers from countries that have already undergone this experience ( $\mathrm{Zhou}, \mathrm{Wu}$, 


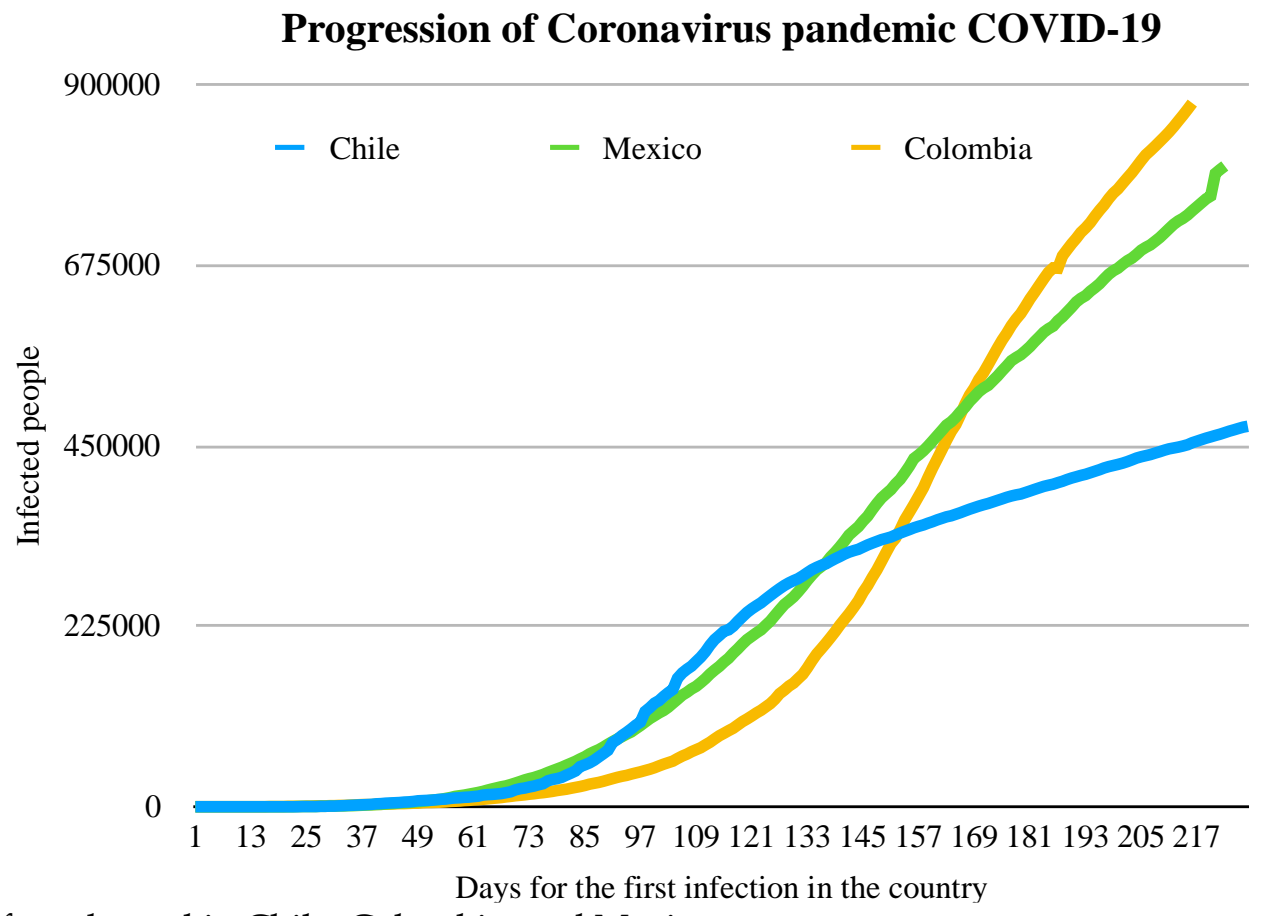

Figure 2. The infected trend in Chile, Colombia, and Mexico

(Source: own elaboration based on John Hopkins University data)

Zhou, \& Li, 2020). According to $\mathrm{UNESCO}^{1}$ data, $37,589,611$ students at all educational levels have been affected in Mexico, while in Chile and Colombia 4,981,092 and 12,842,289 children have been affected, respectively. The closure of schools in Latin America, and particularly in Chile, Colombia, and Mexico, has led governments and their Ministries of Education to seek alternative measures so that affected students can continue their studies from their homes. However, such measures have revealed severe and diverse difficulties, both for teachers at different educational levels and for students and their families, in the attempt to move classes from classrooms to homes.

As a result of the social pandemic disruption that we are experiencing, and when trying to implement actions for the educational system, we question the existing educational paradigm, and we raise generic but crucial questions about actions to be taken and how research can support education stakeholders who participate in these educational processes.

This paper intends to highlight needs that may give way to a research agenda in Mathematical Education motivated by the social demands that have arisen in the pandemic context. Such research needs have arisen for the first time in the social context that we live in today, but many others have been investigated for some years, although perhaps without the necessary emphasis. In the next section, this paper will delve into the measures adopted by the Latin American Ministries of Education, particularly those of Chile, Colombia, and Mexico, highlighting the social needs and demands that have been revealed by the implementation of such measures.

\section{LATIN AMERICAN COUNTRIES' RESPONSE TO THE IMPACT OF THE COVID-19 PANDEMIC: IMPLICATIONS FOR EDUCATION}

The closure of educational institutions in most Latin American countries, as a containment measure against the spread of COVID-19, according to UNESCO data have affected, in all educational levels, 114,230,448 students. Figure 3 shows, by educational level, the number of students affected by school closure.

The Education Ministries implemented measures to ensure that education continues despite the closure of schools and universities, in order to mitigate the effects of educative institutions closure (the delay in the training of students during 2020, the emotional impact). The Ministries of Education of Chile, Mexico and Colombia took the decision to close kindergartens, schools, colleges, universities, and technical education institutions, and as a contingency measure, they decided to continue the 2020 school year using telematic systems, sending both students and teachers to their homes. In Chile and Mexico, this program was called "I learn at home" and "I learn online" respectively, while in Colombia, it was called "Digital learning."

In Chile, the "I learn at home" 2 program consists of a web page where materials for all school levels can be

1 Source: https://es.unesco.org/COVID19/educationresponse

2 Source: https:/ / curriculumnacional.mineduc.cl/estudiante/621/w3-propertyname-822.html 


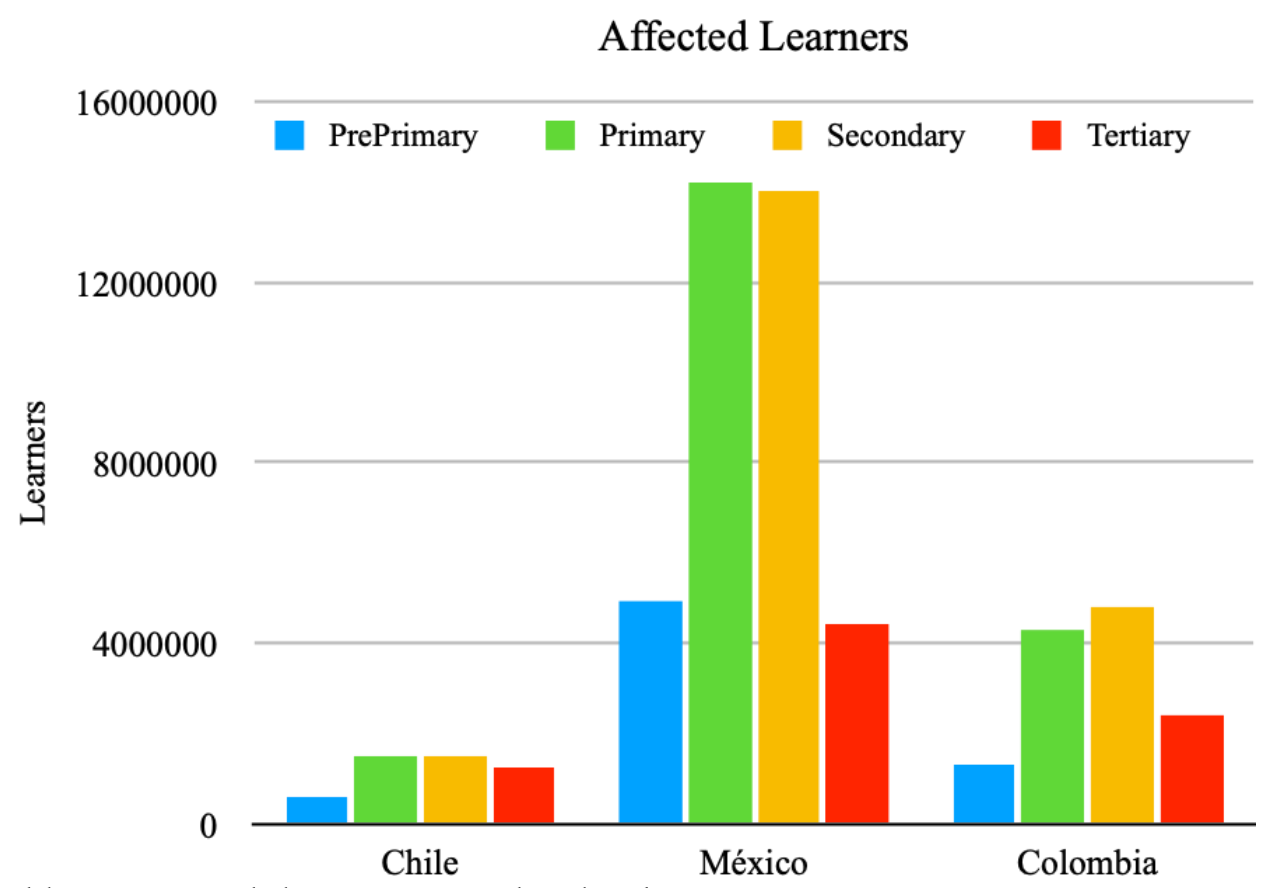

Figure 3. Affected learners in Chile, Mexico, and Colombia

(Source: own elaboration on UNESCO data)

found, from preschool to middle school. This program included the sending of didactic material to rural schools or remote areas where little or no internet connection was available. However, it was the educational institutions responsibility to complement such material through the design and implementation of virtual classes. In the case of higher education institutions, the strategy was to implement online platforms to sustain virtual classes. The situation in Mexico ${ }^{3}$ and Colombia ${ }^{4}$ was similar, students in primary and upper secondary education could access an educational electronic document repository located on a webpage; in the case of Mexico, the television was at students and teachers disposal, and universities were autonomous for implementing classes according to their resources.

However, what is happening with the implementation of measures proposed by Latin American Ministries of Education? Who is responsible, in this pandemic context, for the education of students? Are the measures being implemented by the Ministries of Education functional considering the context in which the vast majority of Latin American society lives? How prepared is Latin-American society to proceed with child and youth education in emergency contexts such as the one we are experiencing? It can be affirmed with the evidence at hand from many Latin American countries that the region is not prepared to face educational processes in pandemic or emergency contexts such as the ones we are experiencing today. Several difficulties and needs have emerged for students, families, teachers, and educational institutions during the short time in which virtual classes and homeschooling methods have been implemented.

One of the first limitations or needs that was manifested during implementation of the measures issued by the Ministries of Education is lack of internet connectivity and, in some cases, access to computers, tablets, and other devices by teachers and students alike and in all educational levels. Concerning this, organizations such as the World Bank, Organization for Economic Co-operation and Development (OECD), and the United Nations (UN), have carried out studies in Latin America on income, socioeconomic strata, educational levels, and on how countries have been trying to improve inhabitant living conditions (food, housing, education, home computers, and internet access). Figure 4 shows the percentage of the population of 18 Latin American countries according to their income.

In the case of Chile, Mexico, and Colombia, 37.2\%; $76.3 \%$; and $57.9 \%$ of the population, respectively, belong to a low socioeconomic stratum. This means that, on average, the Latin American population belonging to this socioeconomic stratum earns less than USD 300 per month. According to the World Bank data, in year 2018 the poverty rate in Mexico reached $34.8 \%$, in Colombia, around $27.6 \%$, and in Chile $6.4 \%$.

The latter highlights the fact that internet access and the acquisition of electronic devices are not universal in Latin American countries. In addition to low incomes, there are rural areas where internet is intermittent or 


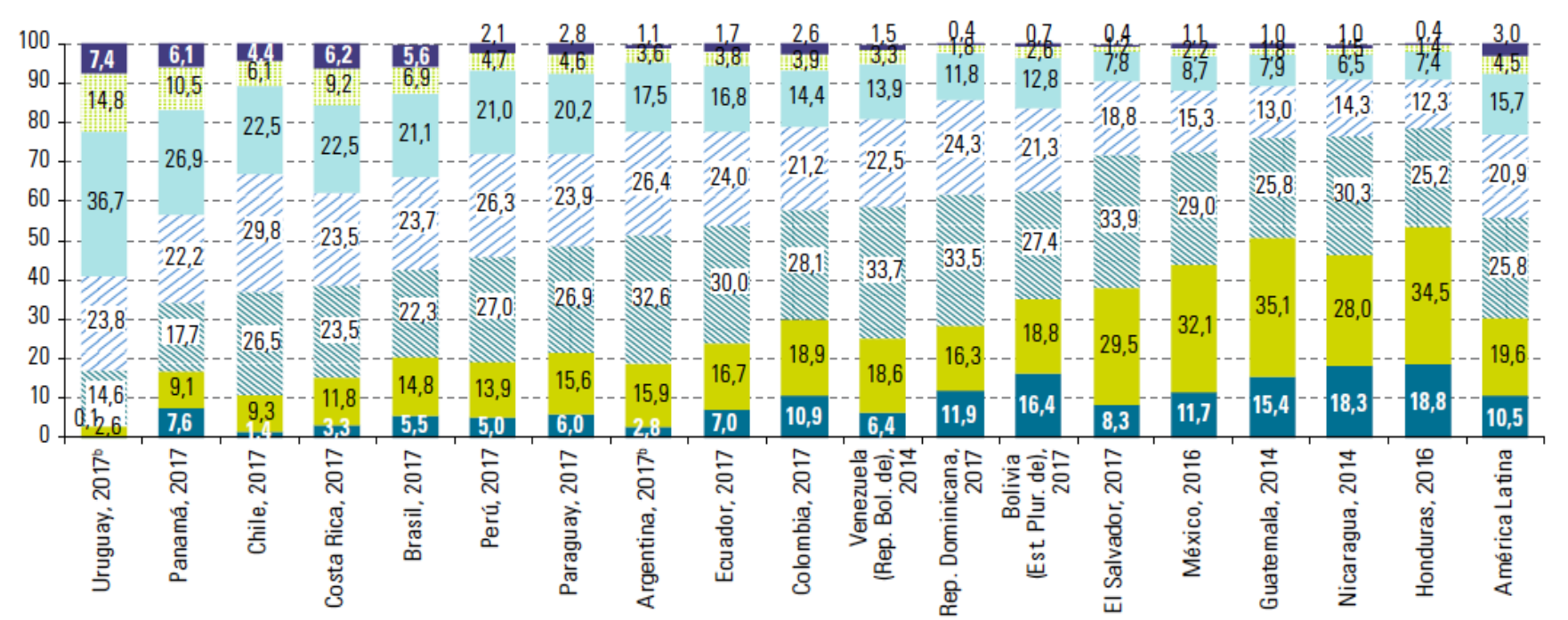

En pobreza extrema $\quad$ En pobreza no extrema $\mathbb{N}$ Bajos no pobres Estratos bajos

Y/Medio-bajos Medio-intermedios Medio-altos Estratos altos Estratos medios

Figure 4. Latin American population according to social stratum (Source: CEPAL, 2019, p. 60)

does not exist; likewise, students are required to have up-to-date computers that allow the management of educational programs and applications. The Economic Commission for Latin America and the Caribbean (ECLAC) reports that only $50.9 \%$ of Mexicans, $49.9 \%$ of Colombians, and $87.5 \%$ of Chileans have internet access. Although both students and teachers can indeed connect with their mobile phones, the connection cost is very high and not everyone has the possibility to hire an unlimited internet service data provider ( $3 G$ and $4 G$ ). On the other hand, due to compatibility issues, not all cell phones can be used with existing educational platforms, nor can all devices be used for academic paper reading.

Regardless of the debate on the effectiveness of school closings as an effective measure to control the pandemic, previous studies suggest that periods of "face-to-face out-of-school" have a more significant impact on the most vulnerable population groups (van Lancker \& Parolin, 2020). Teaching entirely online from home, synchronously or asynchronously, involves a series of 'invisible' circumstances, up to now, for education, but which affect educational processes from the perspective of both students and teachers. For example, students having parents or relatives working online at home, without adequate spaces to carry out their academic activities must create new habits to adapt to the new educational modality, which is a factor that hinders adequately completing the teaching and learning processes. In short, the management of student education in this new environment is complex, and the teacher cannot be taken as the only education stakeholder responsible. It seems that this is the chance for families to take a leading role in the education of their children. Razeto (2016), and Sánchez, Reyes, and Villarroel (2016) report that parent involvement in child school education directly impacts child school performance. However, the situation caused by the pandemic in the families where everyone works makes it more challenging to manage a home education considering it has to be combined either with online or with face-to-face teaching and the difficulty of having to find someone to take care of the children. According to scientific evidence, alternatives such as homeschooling only work in families with economic resources and cultural capital and are not an alternative for the population at large. However, child education is not the sole responsibility of parents or teachers, given that there is an educational policy that, although it recognizes the benefits of the school-community-family alliance, "[educational policy] does not provide a specific work program in schools, probably because it was not created from schools" (Razeto, 2016, p. 196). Currently, most Latin American countries have an educational policy that has not been revisited or updated, despite the transformative processes that society has experienced.

There are still no specific studies that suggest modalities of parental participation in homeschooling, in the actual circumstances, that entail socio-economic and cultural realities experienced by students, as well as the motivation and expectations of parents and educational institutions.

The pandemic teaches us that as a society we must rethink the role that schools (and educational institutions) play in society. The family's involvement in mathematics education of children, at least in the Latin American context, is not something that can be assumed 'lightly,' since it involves stressing critical aspects such as inequality. Indeed, not all families have the educational and cultural experiences that allow them to provide adequate support to their children's education. Latin America has one of the highest unschooling rates, 


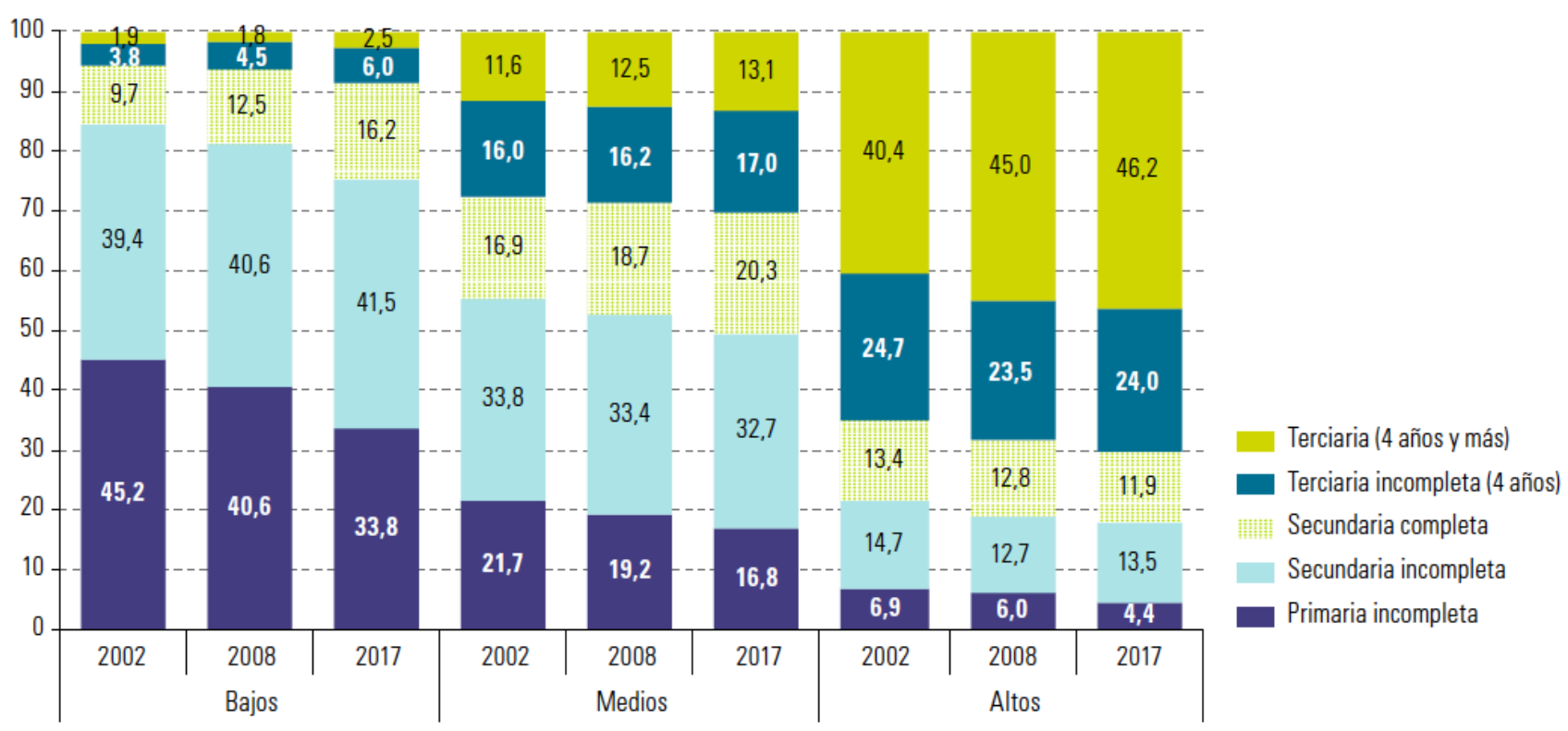

Figure 5. The educational level of the Latin American population over 25 years old by social stratum (Source: CEPAL, 2019, p. 65)

and data from 2017 reveals that in the low and middle strata of the Latin American population, $33.8 \%$ and $16.8 \%$ respectively, have not completed primary school (education from 4 to 12 years old); while $41.5 \%$ and $32.7 \%$, respectively, did not complete secondary education (education from 13 to 18 years of age), as shown in Figure 5.

Additionally, the economic needs of families require that the breadwinners, in some cases due to the pandemic, work in their homes while others must go out to work to obtain the daily income, which has the consequence of not allowing parents enough time to dedicate to the education of their children. The question remains, what about children who do not have families or homes?

In a scenario like the one, we have been discussing the sociocultural approaches of Mathematics Education gain importance, providing a broader view of traditional features involved in the teaching-learning process. Gorgorió, Prat, and Santesteban (2006), propose three sociocultural perspectives for school mathematics: the first considers mathematics as a human product that can respond to society problems at certain times and places; the second, more critical perspective, raises the social and political difficulties implicit in mathematical knowledge for the most segregated societies, increasing social gaps and cultural, economic, racial or gender inequalities; and the third is related to the ability to conceive the mathematics classroom as a stage for social and cultural interactions, where knowledge and the sense of membership to society are socially constructed.

These perspectives suggest that the interaction among students, teachers, and mathematics occurs within a social macro context, and in the specific case of the current pandemic, further reveals individual socioeconomic vulnerabilities in a broader global picture. Inequality has been transferred to the private space, those who suffer the most are the ones who live in environments that are more precarious and invisible by modern society, such as rural people, indigenous people, and those living in extreme poverty, for whom the school system plays a crucial role for their inclusion in society. In the analysis and understanding of this process, Mathematics Education could not only become an opportunity for learning in favor of understanding the world, adopting values and principles such as solidarity, justice, and equality, but it could also politically contribute to the construction of an educational curriculum in favor of equality and social recognition.

Critical Mathematics Education (Valero, AndradeMolina, \& Montecino, 2015), could contribute by proposing new visions, drawing on Mathematical Education, that address the problems that society is experiencing today. Mathematics plays a critical role in the configuration of the social world; therefore, the development of mathematical competence for citizens is vital in decision-making. Now, more than ever, with a global crisis where enormous flows of information and untransparent data confuse, create panic, and misinform population, society needs people who can critically, fairly, and responsibly face the unfavorable circumstances using mathematical knowledge.

This need accentuates the requirement to promote, for example, statistical literacy among citizens (Gal, 2004; Tarran, 2020). Although it is true that the research community in Mathematics Education has recognized this need and carried out studies on it, it seems that much remains to be done. In the context of the COVID19 pandemic, daily we have new statistics that deal with 
the numbers of confirmed virus-infected cases, number of deaths, number of recovered patients, trends, frequency curves, projections, comparisons, statements to 'flatten the curve,' and much more that needs to be understood and critically analyzed, which for the average Latin American citizen is not an easy task.

In Latin America, many citizens do not currently understand the available information regarding the pandemic, and therefore do not understand the seriousness of COVID-19 infections and the importance of accepting movement and personal care restrictions in addition to the importance of educating for life, not standardized evaluations.

The current situation raises a new scenario where technology is not only a tool but has become the means through which the relationship between teachers and students is established. We have little evidence on how, for example, virtual environments affect mathematics learning outcomes, which does not mean that there are not many digital platforms for teaching and learning mathematics, and documents that explain how they work technically. We have a large multitude of digital platforms (commercial and non-commercial), "on-line" educators (some very popular), resources offered by educational administrations, and applications based on artificial intelligence. Some are tools for use that focus on promoting the epistemic suitability ${ }^{5}$ of mathematics, and sometimes also on the cognitive suitability of learning. However, other suitabilities (Breda, Pino-Fan, \& Font, 2017) of learning and teaching mathematics such as interactional or ecological (the relationship with the environment), which have been widely studied and that are known that have a highly relevant impact on learning, have been little considered.

Regarding needs from the teacher's perspective, in addition to what has been commented on, the implications of teleworking and the lack of digital or technological skills have been highlighted (Carvajal, Font, \& Giménez, 2018; Mørk \& Rune, 2014) and the links to diverse mathematics teacher professional competences, such as mathematics, didactic intervention and didactic analysis (Pino-Fan, Font, \& Breda, 2017) also considered. In Latin America, a large number of teachers who have taken on the challenge of teaching online are overwhelmed by the use of technological resources to carry out their teaching practices. In Chile, Colombia, and Mexico, teachers struggle with determining which platforms or software to use for the synchronous virtual classes, finding support for the use of such platforms, determining which strategies are relevant and optimal in telematics environments for teaching mathematics, and how to evaluate student learning.
In the case of Chile, the situation can be seen from two different perspectives, what happens in universities and what happens in stages prior to university. The Universities have to support virtual classes with the use of their own platforms while in the case of the initial education levels it is the educational institutions that have had to assume the responsibility of implementing virtual classes, thus generating situations that give a 'sense of improvisation', through the migration of classroom courses to virtual courses with the use of free platforms such as Google Classroom, Meet, Skype, Google Hangouts, Zoom Free, Blogs, and Social Networks. Similar features have occurred in other Latin American countries. Thus, it is evident the need for the Ministries of Education to make available to teachers platforms that support ideal virtual practices (synchronous and asynchronous). However, what resources are available today to meet the current needs generated by the COVID-19 pandemic?

The use of resources favors designing courses with links to diverse additional sites for the sharing of materials; these are means that allow the teaching of online courses but with a non-dynamic education process. Video-conferencing software and platforms, free or paid, favor conducting online seminars and meetings, sharing notes, communicating via chat, and recording sessions and, although they have excellent characteristics, limit both the connection time and the number of participants. Additionally, they do not support strategies required by teaching processes.

A review of available resources shows that none of them respond to educational needs created by the pandemic, nor to the needs of prolonged confinement. For example, Learning Management Platforms (LMS), combining different resources and functions, allow a virtual classroom where an online course can be fully delivered, and students' progress can be monitored online outside synchronous and asynchronous sessions. Such a learning management system can be installed on a local server or on a cloud server, in both cases a qualified administrator is required for technical maintenance, with fast connectivity and bandwidth available to all being additional requirements.

The review of available platforms shows that they have various attributes that correspond to various characteristics: freeness, usability, robustness, dependability, and secure connectivity (Sommerville, 2016). However, it is difficult to find an educational platform that meets all the needs of various school educational levels and of the different disciplines covered in the curricula. Available resources are not designed to meet diverse teachers' needs since the requirements of a preschool teacher are different from those at primary, secondary, or tertiary level. In addition, non-formal education, technical education,

${ }^{5}$ For an in-depth and critical reading on the notion of didactic suitability, see Breda, Font, and Pino-Fan (2018). 
and education outside the school environment have their own attributes that still need to be studied.

The list of difficulties can be listed as follows: internet availability, educational software, robust platforms, and a bank of resources distributed by educational levels, knowledge and competences of teachers to orchestrate available resources, curricula and educational policies, among others. Everything discussed so far allows us to see that in the context of the COVID-19 pandemic, we need to pause to rethink where we should direct our efforts in education and, specifically, in Mathematics Education. How can the Mathematics Education research community contribute to the future of mathematics teaching? What are the new challenges for the research community in Mathematical Education? The next section will return to these questions in order to reflect on the challenges set for the Latin America Mathematical Education research community.

\section{CHALLENGES FACED BY MATHEMATICS EDUCATION IN LATIN AMERICA: WHAT DOES THE CURRENT PANDEMIC TEACH US?}

It is crucial to know the effect the closure of schools in our area has had. Nevertheless, it is also important to identify successful actions that have taken place in this situation because it is not known if, in the coming months, we will experience similar confinement situations until there are effective treatments or an effective vaccine, with universal access, against the COVID-19 virus. As long as this does not happen one must learn from lessons lived, in conjunction with a rigorous research process, according to the research agenda for Mathematical Education for Latin America. Where could we refocus our efforts so that we contribute to mitigating the impact of COVID-19 on the teaching and learning processes of mathematics in Latin America through research?

The Mathematical Education challenges in Latin America are recognized as being a result of the confrontation between the responses given by the countries to the contingencies caused by the COVID-19 pandemic, socioeconomic characteristics, and the regional educational system' characteristics. These challenges can be grouped into seven themes that give rise to questions that make up a research agenda for Mathematical Education for Latin America: Resources, Curriculum, and the Social Identity versus Teacher Identity of the Teacher, Mathematical Education and Civility, Family-School Links, Professional Practice and Teacher Knowledge, and Educational Policies.

\section{Resources}

Given that in a pandemic context such as the current one, where it is not known if teaching in the immediate future will continue face-to-face, hybrid, or online, it is relevant to assess the suitability of the material and temporal resources used in the instruction processes in this "new normal." Further, research could be oriented to identifying required resources' characteristics for the adaptation by and acceptance of the community. Technology resources, such as podcast videos or audios, could help meet Affordability and Accessibility requirements. However, there are still aspects to be resolved concerning Availability-Adaptability and Acceptability. Research could also investigate the interface between new and old-dated technological solutions and how these could help address Mathematics Education in environments of sustained virtuality based on availability and accessibility.

Other issues to be resolved relate to how to account for the Affordability of different resources in remote regions, in large cities, or in deprived cities zones; what kind of educational adaptations could be made to the resources to fulfill the role of Acceptability and actually favor mathematics learning; how to ensure the adaptability of resources in all types of communities such as indigenous, African-American or immigrant; or how certain resources allow Accessibility to a greater number of students according to the needs of their contexts.

\section{Curriculum}

The COVID19 pandemic has highlighted the need to investigate what changes to the curriculum will be necessary to adapt to the new normal. Mathematics curricula can be viewed as an outline of teaching and learning requirements for content and performance that intends to structure students' learning experiences in school education (Schmidt, Mcknight, Valverde, Houang, \& Wiley, 1997). In Latin America education systems, curriculum is related to various factors, including public policy, curriculum development, school context, teachers, classroom instruction, and student learning. Therefore, it would be expected that the curriculum could be adapted to populations, including minority communities. An additional challenge is that the curriculum should not only be adapted but accepted by communities; it is reasonable to think that rural or indigenous communities might not accept a universal curriculum because it might does not recognize their cosmogony. The design of the curriculum must then be related to technological means that make it Affordable and Accessible, and that, in turn, is Adapted and Accepted by Latin American communities. The four A's involve, in this sense, research to design the curriculum according to the technological resources that support its implementation (Affordable and Accessible), Adaptation, and Acceptance. 
The curriculum design and adaptation has been considered in Colombia, Chile, and Mexico, but the curriculum has been proposed by governments and has left few possibilities for adaptation to educational institutions and schools. Therefore, research on curricular design is required, not only to account for international proposals, but also to recognize the culture of each country and the local needs of mathematical education. The research should address a review of various epistemologies on mathematics, mathematics education, and the social and cultural function of mathematics teaching, while keeping in mind that it seems questionable to teach mathematics as a finished product and not as a process. Investigating the curriculum and its link to culture, and with the social and economic development plans specific to each region, seems to be one of the crucial challenges both for Mathematical Education and for the government entities in charge of educational policies.

\section{Social Identity for Teacher versus Teacher Identity}

The identity of the mathematics teacher has been discussed in several studies (Bjuland, Cestari \& Borgersen, 2012; Boaler, 2002; Sfard \& Prusak, 2005) and now, with the crisis generated by the pandemic, the teacher's social role has been highlighted. Society recognizes the effect of its absence, the Ministries of Education try to regulate its availability, technological resources affect the forms of availability, and the curriculum recognizes the teacher' absence in its design. Children and youth education in an isolated society, programmed or sustained, requires revisiting the society and teacher's role to educate children and youth. These new forms of identity attributed by society must interact with the identity of the teacher, in attention to the social, labour, and technological conditions that regulate interaction. Beliefs about government, social, parenting, teacher, and student mathematics education should be the subjects of inquiry. The challenge that the mathematics' education research community must address in this regard relate to the teacher's role in and out of the school, education by virtual means and in home environments with a diversity of technologies, curricula adapted to populations, education with the help of parents or guardians and with attention to society's needs.

\section{Mathematics Education and Civility}

The society organizes the school to educate its citizens to be active, responsible, competent members in solving problems. Mead (1934) affirms that school initiates children in their own culture and that education is central to ensuring citizens share values and purposes. 'Civility' refers to a civic virtue for participation in democratic life; civility concerns "how citizens encounter each other and exchange ideas and interests in the public sphere" (Peterson, 2019, p. 7). Although the concept of civility has been widely studied (Nehring, 2011; Thomas, 2018), it is necessary to investigate mathematics and science values, which can be discussed, explored, and taught to new generations, values such as truth, equity, argumentation, ethical responsibility to socially build useful knowledge so that daily problems are optimally solved in response to social, health, economic, and environmental restrictions, among others.

Education and its daily school exercise are "... essentially moral and political matters and the question is not whether schools play a role in shaping children's sociability but what this role consists of and how the role is fulfilled" (Peterson, 2019, p. 51). Bishop (1991) identified four levels where values are exhibited at the social, institutional, educational, and individual levels. Values of truth, argumentation, and co-responsibility could help the implementation of social measures of selfrestriction and self-regulation, such as confinement. Studying mathematics values and including them in culturally shared values could help mitigate circumstances that contributed to the spread of the virus, such as lack of social stewardship, selfishness in sharing resources, and manifestation of actions that aggravate the state of the circumstances. Never before in modern humankind history could science's values and citizens' social values save lives like today. Mathematics education and civility could be put to work, while the family and the school meet again to share purposes and tasks.

An education to promote civility could favor the collective construction of an ethical and caring culture, which, however, requires research to identify the type of culture that is required and how to implement it so that society can collaborate, critically, purposefully, and informed by mathematics and statistics. Another challenge to be assumed by the research community in mathematics education is to make mathematics education for citizenship compatible with the mathematical and statistical alphabetization that allows them to understand the world.

\section{Family-School Link}

Today, more than ever, it is necessary to investigate the family and school link, together with its impact on human development and the education of new generations. According to some researchers (Meza \& Paez-Martinez, 2016), the family tends to consider the school a 'nursery' or a safe place where their children can be watched and fed, while parents work. The school, for its part, proposes peripheral family participation in curricular issues and institutional planning. Some studies report that parental involvement is strongly related to students' academic performance (Epstein, 1994), in addition to that, students' mathematical learning improves when schools adopt and develop parents as intellectual resources (Civil \& Bernier, 2004). 
Students' mathematical learning is affected by both parenting at home and teaching at school (Knapp, Landers, Liang, \& Jefferson, 2017). However, the relationships of the school with the family tend to be more bureaucratic and punitive than collaborative. The COVID-19 contingency has revealed that the relationship between school and family must be redefined in order for the objectives of mathematics education and citizenship to be achieved at home with the guidance of teachers and with the help of parents.

There are different approaches, traditional and nontraditional (Latunde, 2017), for active and constructive collaboration between family and school. The traditional approach proposes volunteering, meeting attendance, fundraising, and homework help. The non-traditional approaches become more relevant in contingency situations, among them distance volunteering, parent interaction on learning strategies or on behavioral challenges, family encouragement of reading and learning, teachers who learn about their students' families and how to involve families in education, families that advocate for the learning needs of students and appropriate practices for those needs, schools that works with families to identify needs and emotional or economic deficiencies in the community or neighborhood.

While the approaches presented are relevant, there are questions to be answered. How to make these approaches applicable and possible? How to achieve the active participation of families in school? What conditions should be considered by schools and universities to promote bonding with families? What weaknesses, opportunities, and strengths do the educational systems of Latin American countries have to link family and school? How can school success through family support in the contexts of social vulnerability be measured? How can school and family cooperate for student achievement?

\section{Professional Practice and Teacher Knowledge}

Despite the ubiquity of technological resources, it is common to find that some teachers do not have the knowledge, skills, experience, or external help to effectively integrate technology in classes (Carvajal, Giménez, Font, \& Breda, 2018). This aspect deserves to be investigated by different theoretical approaches and methods. Some researchers (Bozkurt \& Ruthven, 2017; Gueudet \& Trouche, 2009) have examined teacher practices when incorporating new technologies in education and have found that the process of teaching technology-integrated math lessons is mostly based in the teacher's knowledge.

Other studies have recognized that the educational use of technology requires different skills necessary for the mathematics teacher to "reason with", "believe in", and "teach with" technology (Lobo da Costa, Galvão, \&
Prado, 2017); in turn, others have considered that it is necessary to identify different components of the teacher's didactic-mathematical knowledge related to technologies (Pino-Fan, Assis, \& Castro, 2015). Getenet (2017), and Mishra and Koehler (2006) propose a framework to integrate technology with content and pedagogical knowledge. Integration requires the coordination of various facets of teaching processes (Pino-Fan, Assis, \& Castro, 2015), such as the epistemic nature of mathematics, interactions, technological resources and the context in which technology is used. The teachers' role, the mathematical curriculum, and the purpose of the mathematical education is problematized, and calls for questions to be included in a research agenda.

Some questions that can be asked are: How does a technological component favor the training of mathematics teachers and their professional development? How does the epistemology of mathematical objects vary when using technologies, and how does the teacher become aware of it? How can professional development programs that allow the promotion of technology inclusion practices in class, face-to-face, virtual, synchronous or asynchronous, be proposed? What aspects could favor or prevent the inclusion of different technologies in teaching practices at different educational levels? What kind of model of teacher knowledge could account for teacher knowledge in Chile, Colombia, and Mexico? How can classroom lesson practices be studied in a virtual context? The above challenges can be assumed based on the existence and adequacy of public policies that promote research and the use of its results for decision-making.

\section{Educational Policies}

The pandemic has raised problems and questions related to education and the responses that society expects in the face of contingencies, such as the one generated by COVID-19. Government and social responses are articulated through public policies. According to Birkland (2015), "No single definition may ever be developed, but we can discern key attributes of public policy" (p.9). Attributes refer to: tailored to solve problems, for the public good, proposed and implemented by both the government and private organizations, and ultimately refers to what the government decides to do or not do. Public policies can be reactive in response to an urgent situation, or they can be proactive in response to avoiding a future problem. The pandemic confronts us with the need to propose reactive public policies in response to the COVID-19 contingency, which will last for months. However, proactive policies must promote and finance research to respond to needs, questions, and challenges in education and its relationships to the society that questions the technological resources required to attend education in situations of eventual, prolonged, and sustained 
virtuality, the design and role of the curriculum, the role of both society and teacher in the education of ethical, scientific, cultural, environmental, economic, and health values. A discussion on public policies, their design, and implementation, in response to the problems of the pandemic, should be considered by society and by researchers in mathematics education.

\section{CONCLUSIONS}

Given the educational uncertainty that the pandemic brings to Latin America, and in response to the economic, population, geographic, health, industrial, cultural, and technological dependency conditions, among others, it is necessary to revisit the discussion of knowledge and the core foundations of education in Latin American society. The question must be asked again, what is the role of education? In particular, what is the function of education in Latin America? The ensuing response should consider the challenges posed in this document as well as the particularities that define the culture, which shares a language, uses, and customs but which has differences in history, social struggles, indigenous and marginal populations, income distribution, geographic location, and differences of discrimination and marginalization. The pandemic has shown that all are important to combat the spread of the virus and to contribute to achieving an equitable society.

It is worth asking what restrictions or deprivations the educational systems of the various Latin American countries will entail once the crisis is over. This article has presented an overarching discussion on both the effects of the pandemic on the social, economic, and educational aspects of three Latin American countries, which could be assumed as representing the Latin America case, as well as the challenges identified for research in mathematics education, which requires the participation of all education stakeholders to respond jointly to the challenges. The latter involve interaction between societies and the community of mathematical educators -teachers and researchers- so that answers to the questions are given and resources optimized.

However, the expansion of the educational market through different platforms puts the current educational system of the countries at risk, to the extent that, based on how cumbersome, expensive and bureaucratic it is to finance a public education system, it could be provided through technological multinationals and communication companies (Solé Blanch, 2020). It seems a risk that education is placed in the hands of multinationals and that a conception of education is perpetuated in terms of content and not of social, individual, ethical, cultural, and academic competences.

So how do we understand education as a right to citizenship or as a service? This question also makes us reflect on the teaching models and, consequently, on the teacher's role understood as one who teaches to think, to critically analyze, to problematize, to question, and to challenge knowledge, or only as a manager or classroom entertainer. Not only is a teacher required, but society and the family, too. The school is more than a depository platform for knowledge and a site for child and youth care; it is the place where interest in knowledge, social skills, and the discovery of the world is taught through school disciplines. For students it is the place where collective learning takes place and where the world around them is challenged through the understanding of different languages, concepts, models, and instruments that interact with everyday life and decipher other, more complex, worlds.

As education stake holders, rather than surrender without question a 'new' and unknown teaching system, or keep to system's routine of use, or discuss the existence or non-existence of a resource, we should question more vehemently this new form of teaching. Technology should be suitable for educational use and not vice versa. Now is a time to look for other ways of allowing and promoting learning; education cannot remain anchored to the traditional methods that have always marked the western paradigm.

What we are experiencing today cannot be thought of as the education of the future; instead, it must be considered a chance to pause and analyze, probe, and weigh the preparation of the educational environments to face various emergencies or changes that happen in the world. The 'tele-education' discourse cannot be reduced to just a methodological question without the construction of reflective and critical didactics that support it, connected with diverse sociocultural and educational environments.

Now may be the time to search for meeting points in technology, in ethno-mathematics, and in critical mathematics, fields of mathematics education that seem so different (Bishop, 2005). This can allow revisiting the curricular approaches not only of each country but also of each region, allowing the experiences of teachers, students, and families to be included in the school systems according to their needs, narratives, and imaginations. One could speak of a more inclusive, pertinent, and participatory mathematical education in the social and cultural processes characteristic of such a pluralistic and diverse continent. In this sense, it seems that the study of ethno-mathematics has already posed challenges. To give an example, consider that sociocultural factors in teaching, and a methodology to address the demands that arise in education, can be emphasized in the "a) exploration of the variety of social and physical situations that have been and can be explained and illustrated by mathematical methods; b) demonstration and discussion of prediction, efficiency, and control values; and c) the adoption of a critical perspective of society" (Bishop, 2005, p. 81). 
The pandemic has highlighted society's poor preparation as well as its social, industrial, cultural, economic, educational, and health structures, and the absence of 'civic' values to face pandemic disruption in an environment of empathy and co-responsibility. The needs and challenges illustrated in this document propose opening lines of research that should not be assumed as 'reactive' but as proactive.

While the pandemic has exposed poor societal preparation, this has not been caused by the pandemic; the research challenges must continue even after the end of the pandemic in order to achieve answers to the needs discussed in this document. The challenges and lines of research proposed are not made with urgency but with an eye to the future. We are facing an excellent opportunity to analyze education and society, and to review the concepts of knowledge and its use, to understand the world from a new perspective, and to learn that all educational agents must be incorporated to respond to the needs of mathematical education in social, cultural, educational, economic, industrial, health, public management, and political terms. This is an opportunity to advance research in mathematics education through the identification of an agenda for Latin America, with consideration of our limitations and potential.

\section{ACKNOWLEDGEMENTS}

This article has been developed within the framework of the research project Fondecyt 1200005, funded by Agencia Nacional de Investigación y Desarrollo (ANID), CHILE.

\section{REFERENCES}

Artigue, M. (1998). Enseñanza y aprendizaje del análisis elemental: ¿qué se puede aprender de las investigaciones didácticas y los cambios curriculares? Revista Latinoamericana de Investigación en Matemática Educativa, 1(1), 40-55.

Behr, M., Bernard, J., Briars, D., Bright, G., ThreadgillSower, J., Wachsmuth, I., Mason, J., Tall, D., Robitaille, D., Carpenter, T., \& Bookes, W. M. (1984). Research problems in mathematics education: III. For the Learning of Mathematics, 4(3), 22-29.

Birkland, T. A. (2015). An Introduction to the Policy Process: Theories, Concepts, and Models of Public Policy Making (4th edn.). London: Routledge. https://doi.org/ 10.4324/9781315717371

Bishop, A. (2005). Aproximación sociocultural a la educación matemática. Cali: Universidad de Valle.

Bishop, A.J. (1991) Mathematical Values in the Teaching Process. In Bishop A.J., Mellin-Olsen S., Van Dormolen J. (Eds.) Mathematical Knowledge: Its Growth Through Teaching. Mathematics Education
Library, (Vol. 10, pp. 193-214). Springer, Dordrecht. https://doi.org/10.1007/978-94-017-2195-0_10

Bjuland, R., Cestari, M.L., \& Borgersen, H.E. (2012). Professional mathematics teacher identity: analysis of reflective narratives from discourses and activities. Journal of Mathematics Teacher Education, 15, 405-424. https://doi.org/10.1007/s10857-0129216-1

Boaler, J. (2002). The development of disciplinary relationships: Knowledge, practice, and identity in mathematics classrooms. For the Learning of Mathematics, 22(1), 42-47.

Bozkurt, G., \& Ruthven, K. (2017) Classroom-based professional expertise: a mathematics teacher's practice with technology. Educational Studies in Mathematics, 94, 309-328. https:/ / doi.org/10.1007/ s10649-016-9732-5

Breda, A., Font, V., \& Pino-Fan, L. (2018). Criterios valorativos y normativos en la Didáctica de las Matemáticas: el caso del constructo idoneidad didáctica [Evaluative and normative criteria in Didactics of Mathematics: the case of didactical suitability construct]. Bolema, 32(60), 255-278. https:// doi.org/10.1590/1980-4415v32n60a13

Breda, A., Pino-Fan, L., \& Font, V. (2017). Meta didacticmathematical knowledge of teachers: criteria for the reflection and assessment on teaching practice. Eurasia Journal of Mathematics, Science \& Technology Education, 13(6), 1893-1918. https://doi.org/ 10.12973/eurasia.2017.01207a

Carvajal, S., Font, V., \& Giménez, J. (2018). Caracterización de la competencia digital en la formación de futuros profesores de Secundaria a través del análisis sobre su propia práctica. Actas del VIII Congreso Iberoamericano de Educación Matemática (pp. 94-107). Madrid: Federación Española de Sociedades de Profesores de Matemáticas (FISEM).

Carvajal, S., Gimenez, J., Font, V., \& Breda, A. (2018). Creatividad, competencia digital y formación de docentes de matemáticas en secundaria. In Serna, Luis Arturo; Páges, Daniela (Eds.), Acta Latinoamericana de Matemática Educativa (pp. 977984). México City: Comité Latinoamericano de Matemática Educativa.

CEPAL (Comisión Económica para América Latina y el Caribe). (2019). Panorama Social de América Latina 2019. (LC/PUB.2019/22-P/Rev.1). Retrieved from https:/ / repositorio.cepal.org/handle/11362/4496 9

Civil, M., \& Bernier, E. (2004). Parents as intellectual resources in mathematics education: Challenges and possibilities. Paper presented at the research presession of the NCTM, Philadelphia, PA.

Cunha, G., Barraqui L., \& de Freitas, S. (2018). Evaluating the use of gamification in mathematics learning in 
primary school children. IEEE Frontiers in Education Conference (FIE). San Jose, CA, USA. https:/ / doi.org/10.1109/FIE.2018.8658950

Epstein, J. L. (1994). Theory to practice: School and family partnerships lead to school improvement and student success. In C. Fagnano \& B. Werber (Eds.), School, family, and community interaction: A view from the firing lines (pp. 39-52). Boulder, CO: Westview Press. https://doi.org/10.4324/9780429 305375-4

Gal, I. (2004). Statistical literacy: Meanings, components, responsibilities. In J. B. Garfield \& D. Ben-Zvi (Eds.), The challenge of developing statistical literacy, reasoning and thinking (pp. 47-78). Dordrecht: Kluwer. https:/ / doi.org/10.1007/1-4020-2278-6_3

Getenet, S.T. (2017). Adapting technological pedagogical content knowledge framework to teach mathematics. Education and Information Technologies 22, 2629-2644. https://doi.org/10.1007/s10639016-9566-x

Gorgorió, N., Prat, M., \& Santesteban, M. (2006). El aula de matemáticas multicultural: distancia cultural, normas y negociación. In: Goñí, J., Matemáticas e Interculturalidad (pp. 7-24). Barcelona: Editorial Graó.

Gueudet, G., \& Trouche, L. (2009). Towards new documentation systems for mathematics teachers? Educational Studies in Mathematics, 71(3), 199-218. https:/ / doi.org/10.1007/s10649-008-9159-8

Hamari, J., Koivisto, J., \& Sarsa, H. (2014). Does gamification work?-a literature review of empirical studies on gamification. Proceedings of the $47 \mathrm{th}$ Hawaii international conference onsystem sciences (HICSS) (pp. 3025-3034). Hawaii, USA: IEEE. https:// doi.org/10.1109/HICSS.2014.377

Henry, M. (2018). The Online Student Experience: An exploration of first-year university students' expectations, experiences and outcomes of online education (Doctoral dissertation). Edith Cowan University. Retrieved from https:/ / ro.ecu.edu.au/ theses/2059/

Howson, G. (1988). Research in mathematics education. The Mathematical Gazette, 72(462), 265-271. https:/ / doi.org/10.2307/3619938

Inglis, M., \& Foster, C. (2018). Five decades of mathematics education research. Journal for Research in Mathematics Education, 49(4), 462-500. https://doi.org/10.5951/jresematheduc.49.4.0462

Johnson, R. D., Hornik, S., \& Salas, E. (2008). An empirical examination of factors contributing to the creation of successful e-learning environments. International Journal of Human-Computer Studies, 66(5), 356-369. https://doi.org/10.1016/j.ijhcs. 2007.11.003
Kennedy, E., \& Smolinsky, L. (2016). Math Circles: A tool for promoting engagement among middle school minoritary males. Eurasia Journal of Mathematics, Science $\mathcal{E}$ Technology, 12(4), 717-732. https:/ / doi.org/10.12973/Eurasia.2016.1223a

Knapp, A., Landers, R., Liang, S. \& Jefferson, V. (2017).We all as a family are graduating tonight: a case for mathematical knowledge for parental involvement. Educational Studies in Mathematics, 95, 79-95. https:/ / doi.org/10.1007/s10649-016-9741-4

Latunde Y.C. (2017). Research in Parental Involvement. New York: Palgrave Macmillan. https: / / doi.org/10.1057/978-1-137-59146-3

Lobo da Costa N., Galvão M., \& Prado M. (2017). Integration of Digital Technologies in Mathematics Teacher Education: The Reconstruction Process of Previous Trigonometrical Knowledge. In: Aldon G., Hitt F., Bazzini L., Gellert U. (Eds.) Mathematics and Technology Advances in Mathematics Education (pp. 523-550). Springer, Cham. https://doi.org/ 10.1007/978-3-319-51380-5_24

Long, R. S., Meltzer, N., \& Hilton, P. (1970). Research in mathematics education. Educational Studies in Mathematics, 4(2), 446-468. https://doi.org/ $10.1007 /$ BF00417627

Mead, G. (1934). Espíritu, Persona y Sociedad desde el punto de vista del conductismo social. Buenos Aires: Paidós.

Meza, J., \& Páez-Martínez, R. M. (eds.) (2016). Familia, escuela y desarrollo humano. Bogotá, D. C.: Universidad de La Salle, Clacso.

Mishra, P., \& Koehler, M. (2006). Technological pedagogical content knowledge: A framework for teacher knowledge. Teachers College Record, 108(6), 1017-1054. https://doi.org/10.1111/j.14679620.2006.00684.x

Mørk, F. R \& Rune, J. K. (2014). Development of student teacher's digital competence in teacher education. Nordic Journal of Digital Literacy, 9(4), 250-280.

NCTM Research Committee (2015). Grand challenges and opportunities in mathematics education research. Journal for research in mathematics education, 46(2), 134-146. https:/ / doi.org/10.5951/ jresematheduc.46.2.0134

Nehring, H. (2011). 'Civility' in history: Some observations on the history of the concept. European Review of History-Revue européenne d'histoire, 18(3), 313-333. https: / / doi.org/10.1080/13507486.2011.574681

Peterson, A. (2019). Civility and Democratic Education. Publisher: Springer Singapore. https: / / doi.org/10.1007/978-981-15-1014-4

Pino-Fan, L., Assis, A., \& Castro, W. (2015). Towards a Methodology for the Characterization of Teachers' Didactic-Mathematical Knowledge. Eurasia Journal of Mathematics, Science E Technology Education, 11(6), 
1429-1456.

https:// doi.org/10.12973/eurasia.2015.1403a

Pino-Fan, L., Font, V., \& Breda, A. (2017). Mathematics teachers' knowledge and competences model based on the onto-semiotic approach. In B. Kaur, W. K. Ho, T. L. Toh \& B. H. Choy (Eds.), Proceedings of the 41st Conference of the International Group for the Psychology of Mathematics Education (Vol. 4, pp. 3340). Singapore: PME.

Razeto, A. (2016). El involucramiento de las familias en la educación de los niños. Cuatro reflexiones para fortalecer la relación entre familias y escuelas. Revista Páginas de Educación, 9 (2), 190-216. https:// doi.org/10.22235/pe.v9i2.1298

Sánchez, A., Reyes, F., \& Villarroel, V. (2016). Participación y expectativas de los padres sobre la educación de sus hijos en una escuela pública. Estudios Pedagógicos, 3, 347-367. https://doi.org/ 10.4067/S0718-07052016000400019

Schmidt, W. H., McKnight, C. E., Valverde, G. A., Houang, R. T. \& Wiley, D. E. (1997). Many visions, many aims. A cross-national investigation of curricular intentions in school mathematics. Dordrecht:Springer. https:/ / doi.org/10.1007/978-94-011-5786-5

Schoenfeld, A. (2016). Research in Mathematics Education. Review of Research in Education, 40(1), 497-528.

https:// doi.org/10.3102/0091732X16658650

Sfard, A., \& Prusak, A. (2005). Telling identities: In search of an analytic tool for investigating learning as a culturally shaped activity. Educational Researcher, 34, 14-22. https://doi.org/10.3102/ 0013189X034004014

Skovsmose, O. (2012). Explosive problems in mathematics education. For the Learning of Mathematics, 32(2), 5-6.

Solé Blanch, J. (2020). El cambio educativo ante la innovación tecnológica, la pedagogía de las competencias y el discurso de la educación emocional. Una mirada crítica. Teoría De La Educación. Revista Interuniversitaria, 32(1), 297-307. https:/ / doi.org/10.14201/teri.20945

Sommerville, I. (2016). Software Engineering. Boston: Pearson Education Limited.

Tarran, B. (2020), Statistical literacy for all! Significance, 17, 42-43. https:// doi.org/10.1111/j.17409713.2020.01360.x

Thomas, K. (2018). In pursuit of civility: Manners and civilization in early modern England. New Haven, CT: Yale University Press. https:// doi.org/10.2307/j.ctvzpv6kq

Valero, P., Andrade-Molina, M., \& Montecino, A. (2015). Lo político en la Educación Matemática. De la Educación Matemática Crítica a la política cultural de la educación matemática. Relime, 18 (3), 7-20. https:// doi.org/10.12802/relime.13.1830

van Lancker, W., \& Parolin, Z. (2020). COVID-19, school closures, and child poverty: a social crisis in the making. Lancet Public Health, 5(5), e243-e244. https:/ / doi.org/10.1016/S2468-2667(20)30084-0

Wheeler, D., Howson, G., Kieren, T., Balacheff, N., Kilpatrick, J., \& Tahta, D. (1984). Research problems in mathematics education: I. For the Learning of Mathematics, 4(1), 40-47.

Wilson, J. (2020). Reflections on mathematics education research: 1970-1982. Journal for research in mathematics education, 51(1), 3-11. https:// doi.org/10.5951/jresematheduc.2019.0004

Zhou, L., Wu, S., Zhou, M., \& Li, F. (2020). 'School's Out, But Class' On', the largest online education in the world today: taking china's practical exploration during the COVID-19 epidemic prevention and control as an example. SSRN Electronic Journal, 4(2), 501-519. https:// doi.org/10.15354/ bece.20.ar023

\section{http://www.ejmste.com}

